\title{
Configuration of Metallic Ring for Heating Element to Treat Hyperthermia
}

\author{
T. Takura, T. Maruyama, F. Sato, H. Matsuki, S. Aiba*, and T. Sato** \\ Graduate School of Engineering, Tohoku University., 6-6-05 Aoba, Aramaki, Aoba-ku, Sendai 980-8579, Japan \\ *Graduate School of Medical Sciences, Tohoku University., 2-1 Seiryou, Aoba-ku, Sendai 980-8575, Japan \\ ** NEC Tokin Corporation., 6-7-1 Koriyama, Taihaku-ku, Sendai, Miyagi 982-8510, Japan
}

\begin{abstract}
Hyperthermia is a method of treating cancer that uses heat to destroy tumors. Soft heating has been proposed as one method of treating hyperthermia. This is where the thermosensitive ferrite inserted into the tumor as a heating element produces heat in a high-frequency magnetic field. Although the heater needs to be implanted the heater in the tumor tissue, there are various advantages to soft heating, such as easy retreatment, localized heating of the tumor, and a low degree of invasiveness. We applied soft heating in this study. We created a complex heater composed of thermosensitive ferrite wound on a metallic ring. It produced a greater amount of heat due to losses through hysteresis and inductive current than thermosensitive ferrite alone. We could also control the temperature of the heater by using the Curie-point. To use this technique, it is necessary to miniaturize the element and achieve optimal performance. We demonstrated that the proposed heater has superior performance and operation at high power.
\end{abstract}

Key words: soft heating method, thermosensitive ferrite, Curie-point, metallic ring, plating

\section{ハイパーサーミア用発熱体における金属環の構成に関する検討}

\author{
田倉哲也，丸山赴，佐藤文博，松木英敏，相場節也*，佐藤忠邦** \\ 東北大学大学院工学研究科, 宮城県仙台市青葉区荒巻字青葉 6-6-05（率980-8579） \\ *東北大学大学院医学系研究科, 宮城県仙台市青葉区星陵町 2-1（豆980-8575） \\ **N E C トーキン株式会社，宮城県仙台市太白区郡山 6-7-1（广982-8510）
}

\section{1. はじめに}

ハイパーサーミア1)とは, 物理的にエネルギーを加えて全身ある いは局所的に体温を上昇させ，がんや悪性腫瘍などの疾病に対し， 壊死や増殖阻止に至らせる治療法のことである.これは，がん組 織の生存率が $42.5{ }^{\circ} \mathrm{C}$ 以上で急激に低下寸るが, これが正常組織の 壊死温度よりも $1.5{ }^{\circ} \mathrm{C} ほ と ゙$ 低いことに基づいている. 寸なわち, 患部を $42.5{ }^{\circ} \mathrm{Cから} 44{ }^{\circ} \mathrm{C}$ 程度に加温することで，選択的にがん組 織のみを壊死させる治療法が可能となる.

ハイパーサーミアには RF 誘電加温, 超音波加温, $\mathrm{RF}$ 誘導加温, マイクロ波加温等様々な加温法があるが,これらは加温部位の制御 や温度モニタリングが困難であり，発熱体を体内に埋め込むイン プラント加温法が見直されている. インプラント加温法では, 治 療前に発熱素子を患部に埋め込む必要があるが，外部から非接触 で加温ができるため，ケーブル等の皮膚貫通などに起因する細菌 感染の危険性の減少，再治療が容易である，発熱体周囲のみの局 所的な加温が可能であるといった特徵がある.

今回は, 加温方式に我々が既に提案しているソフトヒーティ ング法 2), 3) と呼ぶ加温法を応用し, 高機能力且つ高出力化を目標と して最適な金属環厚を目指した素子を設計し，素子の解析および 温度上昇特性の測定および比較を行った。

\section{2. ソフトヒーティング法}

ソフトヒーティング法とは, 感温磁性体と呼ばれる常温近傍の 比較的低い温度領域にキュリ一点を持つフェライトを発熱体とし これを体内に埋め込み，体外部から高周波磁界で励磁して発生す るヒステリシス損などを発熱源とする加温方式である. ソフトヒ ーティング法では，小型の素子を用いるために体内の深部を局所 的に加温することが可能であり，また感温磁性体のキュリー点を
参照する加温方式であるために温度測定が不要になる, といった 利点がある.

発熱体として今回用いたものは，発熱量をより増大させるため に感温磁性体に金属短絡環をメッキにより構成した複合型発熱体 である．複合型発熱体では，感温磁性体は主に鎖交磁束制御とし てはたらき，金属短絡環によるジュール熱が発熱源として用いら れる.

複合型発熱体の動作原理を Fig. 1 に示す。ここで，発熱体の温 度を $\mathrm{T}$, 感温磁性体のキュリー温度を $\mathrm{T}_{\mathrm{C}}$ とすると, $\mathrm{T}<\mathrm{T}_{\mathrm{C}}$ の温度 領域では感温磁性体の効果により磁束が集中され, 金属短絡環に 発生する誘導電流によるジュール熱で発熱する[Fig. 1(a)]. 一方, $\mathrm{T}>\mathrm{T}_{\mathrm{C}}$ の温度領域になると, 感温磁性体の磁束集中効果が消滅し, 金属短絡環に誘導電流が流れなくなり発熱が抑えられる[Fig. 1(b)]. このように, 複合型発熱体はキュリー温度を参照温度とする自動 温度制御機能を有する発熱素子であるといえる.

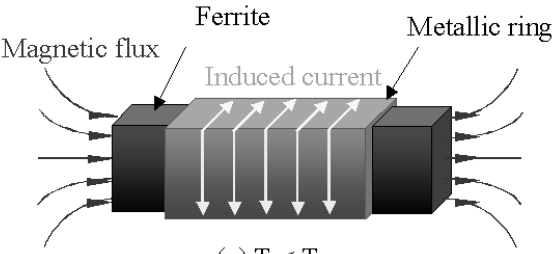

(a) $\mathrm{T}<\mathrm{T}_{\mathrm{C}}$

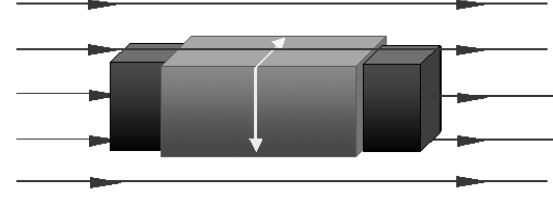

(b) $\mathrm{T}>\mathrm{T}_{\mathrm{C}}$

Fig. 1 Mechanism generating heat in hybrid heater. The temperature o

$\mathrm{T}$, and Curie temperature is TC. 


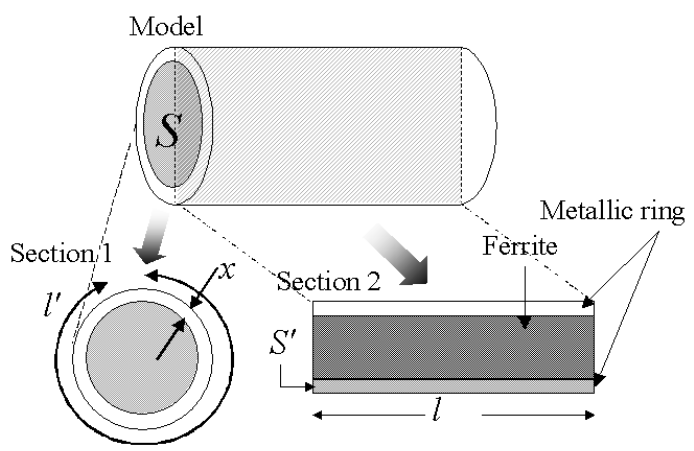

Fig. 2 Models of heating element.

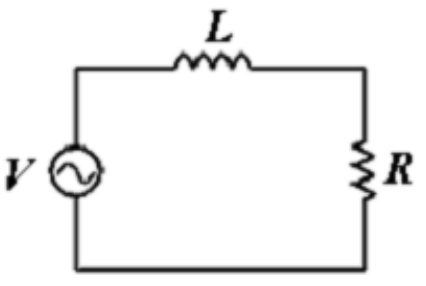

Fig. 3 Equivalent circuit.

\section{3. 金属環厚と発熱量}

\section{1 発熱量の解析}

臨床応用を想定した場合，広範囲の加温を行うために，腫瘍中 心部を高温とすることが必要となる。これを実現するためには, 効率的に熱エネルギ一を供給しなければならない，また，過熱・ 熱暴走のないシステムを構築しなくてはならない，そこで，発熱 素子の詳細な発熱機構の解明と，発熱量の定量的解析を行い，発 熱素子の温度制御性・発熱量の向上を目指した。

実際に使用している素子は角型の素子であるが、計算を容易に するために Fig. 2 のような円柱近似モデルを解析に使用する.

Fig. 2 のようなモデルと考えると, 発熱素子は微小な 1 ターンコイ ルとみなすことができるため, LR 直列回路 Fig. 3 と等価的に置き 換えることができる. 電源となる電圧 V は誘起電圧である. イン ダクタンス $\mathrm{L}$, 抵抗 $\mathrm{R}$, 及ひ誘起電圧 $\mathrm{V}$ はそれぞれ発熱素子の形状, および外部磁界によって定まる.

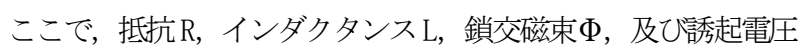
Vはそれぞれ以下の式で表される.

$$
\begin{aligned}
& R=\rho \frac{l^{\prime}}{S^{\prime}}=\frac{\rho l^{\prime}}{x l} \\
& L=\frac{K \mu_{0} \mu_{\text {eff }} S N^{2}}{l} \\
& V=\frac{d \Phi}{d t}=\mu_{\text {eff }} B S \omega \cos \omega t
\end{aligned}
$$

$S$ : フェライトの断面積, $l$ : フェライトの長さ, $S^{\prime}$ :金属環の断 面積, $l^{\prime}$ : 金属環の電流路の経路長, $x$ :金属環の厚さ, $\rho$ :金属 環の抵抗率, $\mu_{0}$ : 真空の透磁率, $\mu_{\text {eff }}$ : フェライトの実効透磁率, $N$ :金属環の巻数, $\Phi$ : フェライトの鎖交磁束, $B$ :磁束密度, $K$ :長岡係数, $\omega$ :磁界の角周波数, $t$ : 時間. 上記の式と等価回

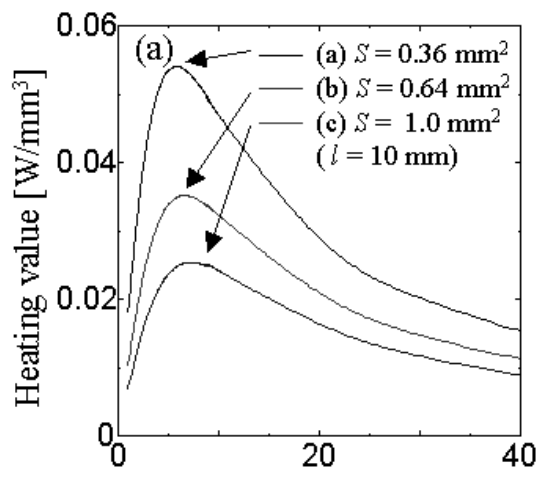

Resistance $[\mathrm{m} \Omega]$

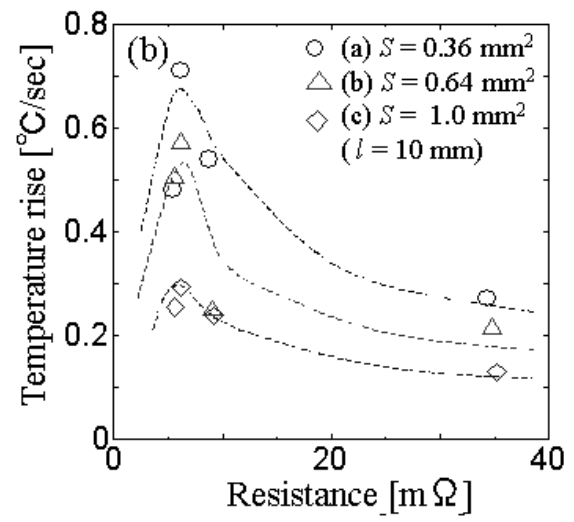

Fig. 4 Resistance characteristics of heating element. (a) Calculation of heating value. (b) Dependence of temperature rise on change in resistance.

路より, 発熱素子の発熱量は以下の式で表される.

$$
P=\frac{R\left(\mu_{e f f} B S \omega\right)^{2}}{R^{2}+(\omega L)^{2}}
$$

この式から供給電力最大の法則より, 抵抗 $\mathrm{R}$ における発熱量が 最大となるのは抵抗值とリアクタンス值が等しいとき，すなわち， $\mathrm{R}=\omega \mathrm{L}$ とさである.

\section{2 発熱量解析の妥当性}

以上より，抵抗值を $\mathrm{R}=\omega \mathrm{L}$ と設定することにより最も効率的 な高発熱となると考えられる. この考えに基づき, 計算を行った 結果を Fig.4 (a) に示寸. 次に, 3 通りの形状について, 抵抗值 の異なる発熱素子について, 発熱特性の測定を行い, 評価を行っ た. 使用した発熱素子は以下に示すとおりである.

(1) 発熱素子 $1:$ フェライト: $\mathrm{N}-204\left(\mathrm{Tc}: 90{ }^{\circ} \mathrm{C}, S: 0.36 \mathrm{~m} \mathrm{~m}\right.$, $l: 10 \mathrm{~mm}$ の角柱, 室温時 $\mu$ eff $: 40.4)$ 金属環: 銅テープ(抵 抗: $5.4 \mathrm{~mW}, 6.1 \mathrm{~m} \Omega, 8.8 \mathrm{~m} \Omega, 34.3 \mathrm{~m} \Omega$ )

(2) 発熱素子 2 : フェライト: $\mathrm{N}-204\left(\mathrm{Tc}: 90{ }^{\circ} \mathrm{C}, S: 0.64 \mathrm{~m} \mathrm{~m}\right.$, $l: 10 \mathrm{~mm}$ の角柱, 室温時 $\mu$ eff $: 56.4)$ 金属環: 銅テープ(抵 抗: $5.5 \mathrm{~m} \Omega, 6.2 \mathrm{~m} \Omega, 9.0 \mathrm{~m} \Omega, 34.7 \mathrm{~m} \Omega$ )

(3) 発熱素子 3 : フェライト: $\mathrm{N}-204\left(\mathrm{Tc}: 90{ }^{\circ} \mathrm{C}, \quad S: 1.0 \mathrm{~m} \mathrm{~m}{ }^{2}\right.$, $l: 10 \mathrm{~mm}$ の角柱, 室温時 $\mu_{\mathrm{eff}}:$ 87.6) 金属環: 銅テープ(抵 抗: $5.6 \mathrm{~m} \Omega, 6.2 \mathrm{~m} \Omega, 9.2 \mathrm{~m} \Omega, 35.2 \mathrm{~m} \Omega$ )

結果 Fig.4 (b) より, それぞれの形状の発熱素子で, もっともよ く発熱する抵抗值が存在し, さらに計算值 (Fig.4(a)) と比較する 


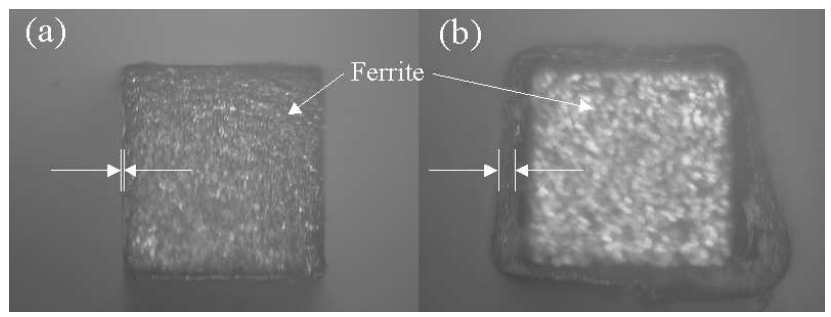

Fig. 5 Photograph of heating element. (a) Metallic coated version. (b) Copper tape version.
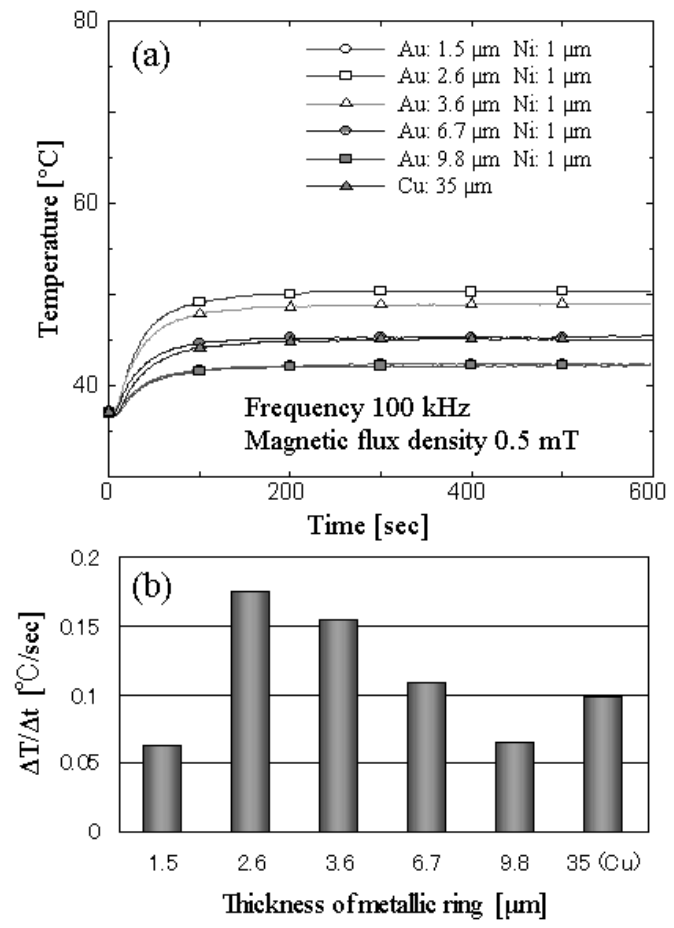

Fig. 6 Temperature characteristics of heating element at low magnetic flux density. (a) Temperature profile. (b) Rate of temperature rise.

と同程度の抵抗值でピークとなっている. これらのことから, 我々 の行っているハイパーサーミア技術においても， R= $\mathrm{R}$ Lという 条件式を適用することが可能である，これは，印加磁界を強める ことなく，発熱量を増加させることができることから，最も効率 的な条件といえる.

\section{3 最適な金属環の厚み}

発熱量の式 (4) を金属環厚 $x$ の関数として式を書き表すと, 以 下の式のようになる.

$$
P=\frac{R\left(\mu_{e f f} B S \omega\right)^{2}}{R^{2}+(\omega L)^{2}}=\frac{A_{1}}{A_{2} x+\frac{A_{3}}{x}}
$$

金属環の抵抗值は，金属環の厚夕に依存するので, $\mathrm{R}=\omega \mathrm{L}$ で発 熱量が最大となるということはつまり，ある金属環厚 $x$ で発熱量 が最大になると言える．最適な金属環厚を，周波数を $100 \mathrm{kHz}$, 発熱素子サイズを $S=0.36 \mathrm{~mm}^{2}, \quad l=10 \mathrm{~mm}, 0.6 \times 0.6 \times$ $10 \mathrm{~mm}^{3}$ ，金属環を $\mathrm{Au}$ で構成した場合について計算すると, 約 2 $\mu \mathrm{m}$ となる.この金属環厚に近づけるためには, フェライトに $\mathrm{Au}$
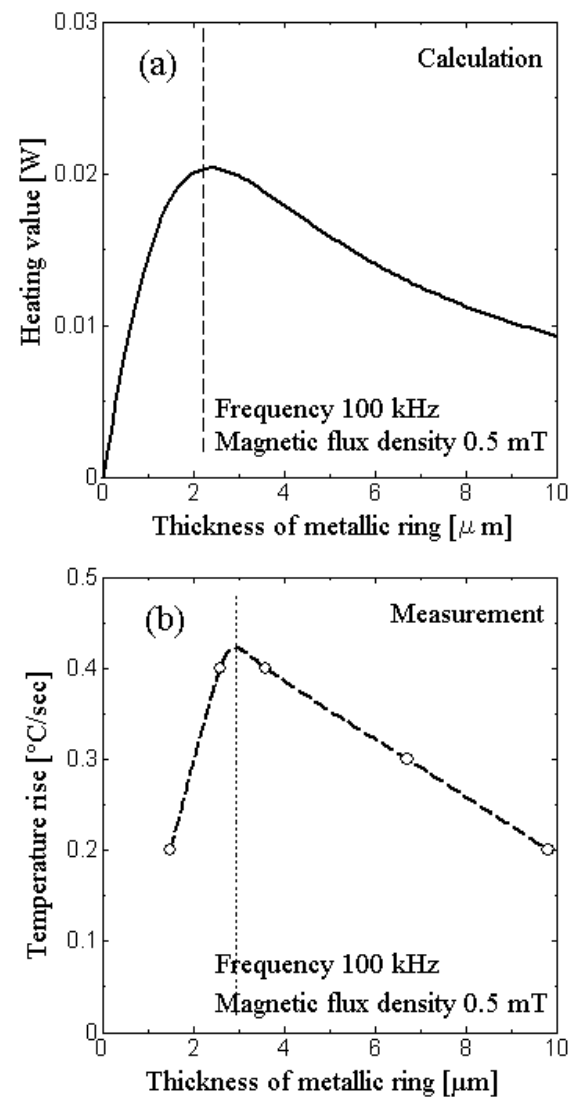

Fig. 7 Metallic ring characteristic of heating element. (a) Dependence of temperature rise on metallic ring thickness. (b) Calculation of heat value.

メッキを施す必要がある.

\section{4. メッキによる効果}

\section{1 実験条件}

そこで今回は, $\mathrm{Au}$ と $\mathrm{Ni}$ によるメッキ処理 (Ni を下地として最 初にメッキし，次に $\mathrm{Au}$ をその上にメッキしている）を $\mathrm{Ni}-\mathrm{Cu}-\mathrm{Zn}$ 系フェライト $\mathrm{N}-193\left(\mathrm{Tc}: 70^{\circ} \mathrm{C}\right)$ に施した (Fig.5). このとき, $\mathrm{Ni}$ の厚さは一定 (約 $1 \mu \mathrm{m}$ ) として, Au の厚さを $1.5 \mu \mathrm{m}, 2.6 \mu$ $\mathrm{m}, 3.6 \mu \mathrm{m}, 6.7 \mu \mathrm{m}, 9.8 \mu \mathrm{m}$ と変化させた発熱素子をそれぞ れ 1 本づつ用意している. ここで, メッキする金属として $\mathrm{Au}$ を選 択した理由は，他の金属に比べて生体適合性が良いからである.

励磁条件としては，周波数は $100 \mathrm{kHz}$ 固定で，磁束密度を 0.5 $\mathrm{mT}$ の場合と $3.0 \mathrm{mT}$ の場合の 2 通りで行った. 使用したコイルは, 直径 $141 \mathrm{~mm}$, 長さ $200 \mathrm{~mm}$, 巻数 141 turns のソレノイドコイ ルである. その理由として，この発熱体の発熱機構が関係してく る. この発熱体は 2 種類の発熱源をもっている. 一つは温度依存 特性をもつものであり, 金属環の中を通る磁束の変化から生じる 誘導電流による発熱がそれに当たる. Fig.1 でも示したように, 発 熱素子を負荷がつながっている一種のトランスとしてみているた め, 二次側のコイルを通る磁束の変化により流れる電流が変化す る. この発熱が温度依存性を有するのは, キュリ一温度をもつフ エライトを使用しているため温度により磁束量が変化するためで ある. もう一つは, 温度依存特性をもたない発熱であり, 発熱素 子をメッキしている $\mathrm{Au}$ を磁束が貫通することによる渦電流損や 
フェライトのヒステリシス損からの発熱である.これは，発熱素 子を磁束が通るときに発生する損失であり, 金属環の厚みを増加 させたり, 励磁周波数・磁束密度を増加させたりした場合に発熱 が増加するが, 発熱素子の温度によらず発生する. しかし, キュ リー温度以下では高い発熱が得られるのに対し, キュリー温度以 上では発熱が止まってしまう4)ことから, 前者の発熱が我々のもつ ハイパーサーミア系において発熱の大部分を占めている.

ゆえに，単純に金属環の厚みの変化による発熱素子の発熱量を 評価する場合, 温度制御がかかるような磁束密度中においては, 発熱が温度制御嘰能により止まってしまうため, 主要な発熱量を 正確に評価することができない，そこで，温度制御がかからない ような磁束密度中において測定する必要がある。

\section{2 金属環厚による発熱量（低磁束密度中）}

周波数 $100 \mathrm{kHz}$, 磁束密度 $0.5 \mathrm{mT}$ 中における, 温度一 時間特性を Fig.6(a)に示す. 温度が平衡状態に到達したと きの到達温度が発熱素子の発熱量を表していると考えられ るので, その到達温度を比較すると, 高い方から A uメッ キの厚さは, $2.6 \mu \mathrm{m}, 3.6 \mu \mathrm{m}, 6.7 \mu \mathrm{m}, 1.5 \mu \mathrm{m}, 9.8$ $\mu \mathrm{m}$ となる. さらに, 温度一時間特性の初期の傾きを表し た Fig.6(b)をみても同様の順番である。この結果から, 先 の解析で得られた発熱の最適条件（金属環厚が約 $2 \mu \mathrm{m}$ ) と大きな違いはない,さらに, 温度上昇率の最大值をとり だした Fig.7(a)と解析から得られた Fig.7(b)を比較しても, グラフの傾向と最大となる值の位置にわずかな差があるも のの, ほぼ同じような傾向を示す (差は約 $1 \mu \mathrm{m}$ ). この差 は, $\mathrm{Au}$ をフェライトにメッキするための $\mathrm{Ni}$ によりずれが 生じたものと考えられるが, この程度の差であれば, 実使 用に何ら問題がない。むしろ, 今回の実験結果より, 今後 使用していくべき金属環厚を決定することができた.

\section{3 温度制御がかかる磁束密度中}

次に, 周波数 $100 \mathrm{kHz}$, 磁束密度 $3.0 \mathrm{mT}$ 中における, 温度一時間特性を Fig.8(a)に示す. これぐらいの磁束密度 になると，どの金属環厚においても温度制御が機能してい るのが確認することができる，さらに，温度一時閒特性の 初期の傾き(Fig.8(b))をみても, 傾きの最大值はどれも変わ らないといった結果が得られている. ただ, やや金属環厚 に比例して到達温度が高くなるといった傾向がみられるが， これは先に述べたように, 温度依存特性がない発熱が寄与 してきているためだと考えられる. 今回，Auメッキ厚が $1.5 \mu \mathrm{m}$ のとだけ, 他の金属環厚の場合と比較して到達 温度が低くなったのは, 金属環厚が薄すぎたために発熱量 のピークから外れているためだと考えられる.もう一つ 9.8 $\mu \mathrm{m}$ のときもピークから外れていたが, この場合, 温度依 存特性がない発熱が金属環厚の増加とともに増えたために $1.5 \mu \mathrm{m}$ のととは違い高い発熱が得られたものだと考え られる。

以上のように，高磁束密度中においての測定を行うことで，温 度制御時における金属環厚が素子の発熱に及ぼす影響を確認する ことができた，金属環厚が増すことにより，発熱素子の到達温度 が高くなる傾向がみられた。 この発熱は先に述べた温度依存性の
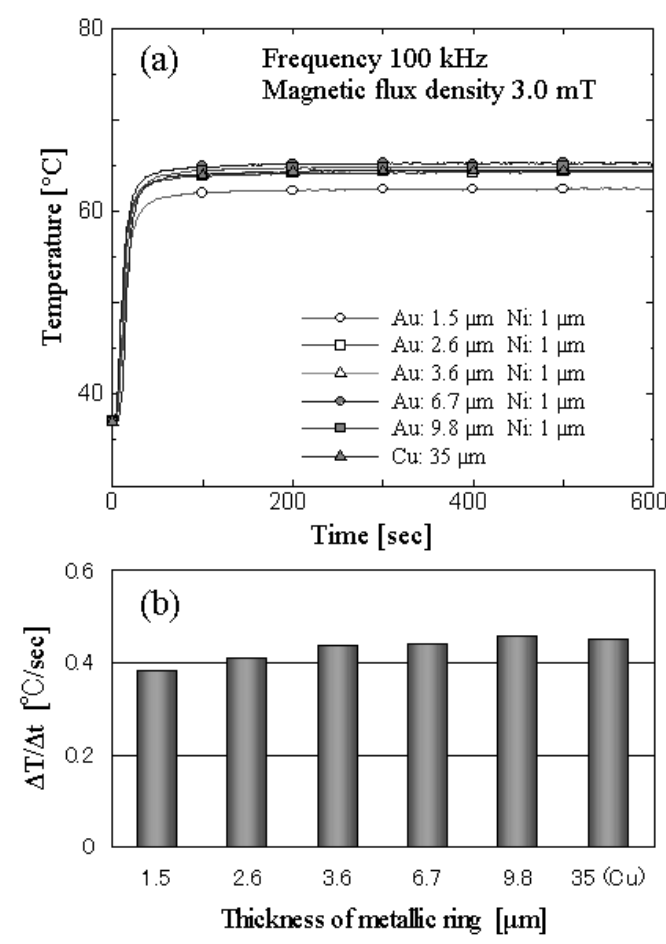

Fig. 8 Temperature characteristics of heating element at high magnetic flux density. (a) Temperature profile. (b) Rate of temperature rise.

無い発熱が寄与していると考えられる. しかし,この結果を基に, 発熱量を稼ぐために金属環厚を厚くした場合, 温度制御点を超え て発熱していくことも予想される. さらに厚くしていくと, 今度 は発熱量のピークからずれていくので，素子自体の温度が上がり 難くなり, 全体の発熱量でみると小さくなる.つまり, 厚すぎ ても薄すぎても発熱素子としては良くなく，その間が条件 として求められる.今回測定した発熱素子の金属環厚の範 囲では，1.5 $\mu \mathrm{m}$ 以外であれば，温度制御に悪影響を及ぼ さず高い発熱を得ることが可能である。しかし，実際のが ん組織では血流により熱が拡散していくので, 制御がかか る温度に到達するまでに時間がかかる，その場合，制御が かからない状態での高い発熱が求められる。ゆえに, $\mathrm{Au}$ メッキを施した発熱素子のメッキ厚としては, $2.6 \mu \mathrm{m}$ 程 度が適している。

\section{5. まとめ}

以上，本検討では複合型発熱素子の発熱機構の解析を行 い, その結果を基に金属環を構成し，発熱素子高発熱化の 方法を提案した。その方法とは, 発熱素子の等価回路にお いて, 抵抗值とリアクタンスが一致する条件においてもっ とも高発熱となり, 印加磁界を強めることなく, 発熱量を 増加させるという点で最も効率的な条件であることが示さ れた．これはすなわち， $\mathrm{R}=\omega \mathrm{L}$ を基にハイパーサーミア 用発熱素子を設計すればよいことになり，発熱素子の設計 が容易になったといえる.また, 本検討における解析では, 一様磁界を発生させる一次側コイルと発熱素子の相互イン ダクタンスは，それぞれのサイズを考慮するとほぼゼロと 
みなすことができるので, その条件で解析を行っているが, 先の計算值と実測值との間に大きな差がなかったことから， 相互インダクタンスを考えずに設計ができるといえる．実 際にソレノイドコイル中に発熱素子を配置してソレノイド コイルの自己インダクタンスの変化を測定してみたが，ソ レノイドコイルの自己インダクタンスに変化は見られなか ったので, やはり相互インダクタンスはゼロとみなすこと ができると考えられる.

さらに, 本検討では, 解析から得られた発熱最適条件に 近づけるために, 発熱素子のフェライトをメッキ化するこ とにより実現した。これにより, 解析通り, 従来の金属環 厚に比べて高い発熱を得ることが可能になった．また，金 属環厚が薄くなったことによる発熱素子の小型化を図るこ ともできた，発熱が高まり，小型化が実現したことで，患 者への負担を減らしつつより確実にガン組織を死滅させる ことが期待される。
謝辞 本研究の一部は, 文部科学省科学研究費「若手研究

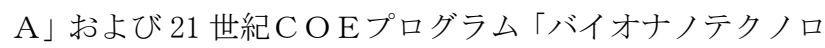
ジー基盤未来医工学」によった.

\section{References}

1) H. Matsuki, and K. Murakami: IEEE Trans. Magn., 21, pp. 1927-1929 (1992).

2) K. Murakami, H. Matsuki: Thermosensitivity magnetism applied engineering, p. 48, Baifukan, Tokyo (1993).

3) H. Matsuki: Bioelectromagnetic Engineering, p. 125, Corona publishing Co., LTD., Tokyo (1999).

4) M. Jojo, F. Sato, H. Matsuki, S. Yamada, and T. Sato: J. Magn. Soc. Jpn., 26, pp. 589-592 (2002).

5) J. Shimizu, F. Sato, H. Matsuki, T. Sato, M. Sendoh, K. Ishiyama, and K. I. Arai: J. Magn. Soc. Jpn., 27, pp. 456-459 (2003).

2006 年 10 月 19 日受理, 2007 年 2 月 6 日再受理, 2007 年 3 月 19 日採録 